\title{
Triatomines Involved in Domestic and Wild Trypanosoma cruzi Transmission in Concepción, Corrientes, Argentina
}

\author{
María Esther Bar/+, Miryam Pieri Damborsky, Elena Beatriz Oscherov, Alicia María \\ Francisca Milano, Gilberto Avalos, Cristina Wisnivesky-Colli*
}

Cátedra de Artrópodos, Facultad de Ciencias Exactas y Naturales y Agrimensura, Universidad Nacional del Nordeste, Av.

Libertad 5470 (3400) Corrientes, Argentina *Unidad de Ecología de Reservorios y Vectores de Parásitos, Departamento de

Ciencias Biológicas, Facultad de Ciencias Exactas y Naturales, Universidad de Buenos Aires, Buenos Aires, Argentina

An entomological and serological survey was performed in three localities of the Department of Concepcion, Province of Corrientes, Argentina in 1998 and 1999, to identify triatomines species involved in domestic and wild transmission of Chagas disease. Triatomines were collected by man/hour capture in 32 houses randomly selected and 44 nearby outdoor ecotopes. Trypanosoma cruzi infection in triatomines was assessed by direct microscopic observation (400x) offeces and polymerase chain reaction. Serological techniques used for people were Indirect Hemagglutination Test and Indirect Fluorescent Test. Triatomines were collected in $28.1 \%$ of the houses and $31.8 \%$ of the wild biotopes. Triatoma infestans (Klug 1834) was exclusively found indoors and T. cruzi infected $60 \%$ of them. Triatoma sordida (Stål 1859) was mainly found in extradomestic ecotopes where trypanosome infection rate reached $12.7 \%$. Serological study of 98 local people showed that $29.6 \%$ were seroreactive; most of their houses were closed to wild biotopes colonized by T. sordida.

Results indicate that there is an active T. infestans mediated transmission of Chagas disease in this zone that yields important human prevalence and that the populations of T. sordida in wild biotopes not only sustain the wild T. cruzi cycle but also represent an actual risk for people living in the area.

Key words: Triatoma infestans - Triatoma sordida - infestation - infection -seroprevalence - Argentina

In rural areas of Corrientes Province, Triatoma infestans (Klug 1834) is mainly found indoors and is also present in peridomestic premises (Bar et al. 1992, 1996b, 1997).

T. sordida (Stål 1859) colonizes wild biotopes (Bar et al. 1996a) as well as artificial ecotopes in peridomestic areas, sometimes coexisting with $T$. infestans and even established inside a rural house (Bar et al. 1992, 1996b). In Corrientes city it frequently invades houses and a large colony was captured in an urban ecotope (Bar et al. 1993).

Although intradomestic colonies of $T$. infestans have been eliminated from some areas of Corrientes province, $T$. sordida may replace it as a domestic vector. Integration of extradomestic triatomines to domestic transmission cycles has been occasionally reported in Minas Gerais, Brazil (Diotaiuti et al. 1993).

Anthropic environmental modification, mainly the replacement of natural forest by cultivated land, harvesting of wood and uncontrolled grazing may produce a concentration of wild mammals and triatomines in the peridomicile, generating local transmission cycles of Trypanosoma cruzi. Those foci can provide invading vectors to the domicile that can eventually carry trypanosomes (Wisnivesky-Colli et al. 1993). The peridomicile may represent a transition environment for triatomines coming from the wild and facilitate their domiciliation process (Gajate et al. 1996).

An important flood affected Corrientes Province in 1998, as a consequence of the El Niño phenomenon, which made the owners of the dwellings leave them temporarily. Most of the houses were rebuilt afterwards.

${ }^{+}$Corresponding author. Fax: +54-3783-473930. E-mail: mebar@exa.unne.edu.ar Received 5 March 2001 Accepted 23 August 2001
This entire situation contributed to the increase of the environmental disturbance.

In order to increase our knowledge on the ecology of domestic and wild triatomines, an entomological and serological survey was carried out in rural settlements of the Department of Concepción, Corrientes.

\section{MATERIALS AND METHODS}

Study area - The study area was situated in the localities of Santa Rosa, Colonia Tabay and Colonia Tata Cuá of the Department of Concepción, Corrientes, Argentina (27 to $28^{\circ} \mathrm{S}$ and $57^{\circ}$ to $58^{\circ} \mathrm{W}$ ). Biogeographically the area belongs to the oriental district of the Chaco region (Cabrera \& Willink 1973).

Socioeconomic characteristics - Most of the houses were built with materials obtained from the environment. Wood walls and sheet metal or cardboard roofs were observed in $62.5 \%$ of the households, the remainder had mud stick walls and thatched roofs. Similar materials were used to built the storerooms and kitchens.

Domestic animals were present in $97 \%$ of the households, of which $80.5 \%$ were dogs, $55 \%$ cats and $53 \%$ hens.

Peridomestic ecotopes were open structures made with sticks or wood, partially covered or not by a roof, 5-20 m far from the domiciles.

The main activities are agricultural production directed to the family subsistence and temporary employment in cattle rearing or in the sawmills.

Field work - Houses were selected at random and nearby outdoor premises like hen and pigeon houses, pens, kennels and wild biotopes (piled trunks, palms, bird nests) were examined. Triatomines were collected by man/ hour capture (Wisnivesky-Colli et al. 1987) using dislodging substances ("Neopynamin": tetramethrin $0.2 \%$ ). The study was carried out during four seasons: spring (1998) and summer, autumn and winter (1999), after the "El Niño" phenomenon. 
Laboratory work - Triatomines were taxonomically determined and classified by sex and instars (Lent \& Wygodzinsky 1979, Carcavallo et al. 1997). Trypanosome infection in collected triatomines was initially assessed by direct microscopic observation of feces (400x). Observed parasites were identified as T. cruzi by PCR of DNA from feces dried on Whatman paper no.1 (Russomando et al. 1996). One pair of specific TCZ primers were used (Mozer et al. 1989).

Human blood was collected from voluntary residents by venipuncture. Diagnosis of Chagas disease infection was performed combining Indirect Hemagglutination Test and Indirect Fluorescent Test. Individuals were considered positive if they were simultaneously reactive in both tests at serum dilution $\geq 1: 32$. Of 163 residents in this area, 98 people were studied, considering a previous estimated $30 \%$ prevalence of infection and a $90 \%$ confidence interval.

\section{RESULTS}

Entomological survey - From a total of 32 houses and 44 outdoor biotopes searched, triatomines were found in 28.1 and $31.8 \%$ respectively. T. cruzi infection was recorded in $60 \%$ of $T$. infestans and in $12.7 \%$ of $T$. sordida individuals.

Total triatomines collected according to stages, species and seasons are recorded in Table I.

Winter - Eight houses and nine peridomestic premises were searched but no triatomine was found. Two out of three wild biotopes were infested by $T$. sordida nymphs $(\mathrm{N}=9)$ and Psammolestes coreodes adults $(\mathrm{N}=3)$. None of them was infected by $T$. cruzi.

Spring - Seven houses were searched and three were infested by $T$. infestans $(\mathrm{N}=19)$. One out of three collected adults was infected by $T$. cruzi. Entomological searches were performed in seven peridomestic premises and three wild biotopes. The $12.5 \%$ of captured triatomines were infected. One infected $T$. sordida female was found in a pigpen. In two wild biotopes we collected 29 T. sordida, mainly nymphs of fifth instar.

Summer - In three infested houses from seven examined, we found $28 T$. infestans bugs including T. cruzi in- fected adults. Hatched T. sordida eggs were found inside a bed. In one peridomicile, numerous fecal streaks of triatomines were recorded.

In $75 \%$ of eight examined wild biotopes a total of $27 \mathrm{~T}$. sordida insects were collected. T. cruzi was detected in $17.4 \%$ of collected wild triatomines.

Autumn - Ten houses resulted to be not infested by live triatomines, however hatched eggs were found in two of them. All of the ten peridomiciles examined rendered negative results.

T. sordida nymphs $(\mathrm{N}=13)$ were collected in two wild biotopes and T. cruzi infection was confirmed in 1fifth instar nymph.

Serological survey - We studied men and women from 1-96 years old that were permanent residents of both infested and non-infested dwellings. The overall prevalence rate of infection by $T$. cruzi in the analyzed population was $29.6 \%$ (Table II). Our data documented a seroprevalence of $12.2 \%$ in children up to 10 years old. Meanwhile the infection rate observed in the following age group was approximately four times greater. Half of all people older than 30 years $(9 / 18)$ were seroreactive. No significative difference was observed between sexes $\left(\chi^{2}=0,36, p=\right.$ $0,56)$.

TABLE II

Human population serologically analyzed for diagnosis of Chagas infection, Concepción, Corrientes, Argentina, 1998-1999

\begin{tabular}{rcccccc}
\hline $\begin{array}{l}\text { Age } \\
\text { (years) }\end{array}$ & \multicolumn{2}{c}{\begin{tabular}{c} 
Analyzed population \\
\cline { 6 - 7 } \cline { 5 - 7 }
\end{tabular}} & Females & Males & & \multicolumn{3}{c}{ Infected population } \\
\hline $0-10$ & 25 & 24 & & 3 & 3 & $6(12.2)$ \\
$11-20$ & 11 & 7 & & 3 & 5 & $8(44.4)$ \\
$21-30$ & 10 & 3 & & 4 & 2 & $6(46.1)$ \\
$31-40$ & 4 & 1 & & 2 & 1 & 3 \\
$41-50$ & 0 & 2 & & 0 & 1 & 1 \\
$>50$ & 5 & 6 & & 3 & 2 & $5(45.4)$ \\
\hline Total & 55 & 43 & 15 & 14 & $29(29.6)$ \\
\hline
\end{tabular}

TABLE I

Triatomines collected in different ecotopes and seassons, according to species and stages, Concepción, Corrientes, Argentina, 1998-1999

\begin{tabular}{|c|c|c|c|c|c|c|c|c|c|c|c|}
\hline \multirow[t]{2}{*}{ Seasson } & \multirow[t]{2}{*}{ Ecotope } & \multirow[t]{2}{*}{ Species } & \multicolumn{8}{|c|}{ Age structure } & \multirow[t]{2}{*}{ Total } \\
\hline & & & $\mathrm{E}$ & $\mathrm{I}$ & II & III & IV & $\mathrm{V}$ & $\mathrm{F}$ & M & \\
\hline \multirow[t]{3}{*}{ Winter } & Wild & T. sordida & 0 & 0 & 0 & 2 & 2 & 5 & 0 & 0 & 9 \\
\hline & & P. coreodes & 0 & 0 & 0 & 0 & 0 & 0 & 1 & 2 & 3 \\
\hline & Peridomestic and domestic & - & 0 & 0 & 0 & 0 & 0 & 0 & 0 & 0 & $\begin{array}{c}0 \\
12\end{array}$ \\
\hline \multirow[t]{2}{*}{ Spring } & Peridomestic and wild & T. sordida & 0 & 3 & 2 & 7 & 3 & 11 & 1 & 3 & 30 \\
\hline & Domestic & T. infestans & 16 & 0 & 0 & 0 & 0 & 0 & 2 & 1 & $\begin{array}{l}19 \\
49\end{array}$ \\
\hline \multirow[t]{3}{*}{ Summer } & Wild & T. sordida & 0 & 9 & 4 & 0 & 4 & 4 & 1 & 5 & 27 \\
\hline & Domestic & T. infestans & 21 & 5 & 0 & 0 & 0 & 0 & 1 & 1 & 28 \\
\hline & Peridomestic & - & 0 & 0 & 0 & 0 & 0 & 0 & 0 & 0 & $\begin{array}{c}0 \\
55\end{array}$ \\
\hline \multirow[t]{2}{*}{ Fall } & Wild & T. sordida & 0 & 6 & 0 & 2 & 2 & 3 & 0 & 0 & 13 \\
\hline & Peridomestic and domestic & - & 0 & 0 & 0 & 0 & 0 & 0 & 0 & 0 & $\begin{array}{c}0 \\
13\end{array}$ \\
\hline
\end{tabular}

E: eggs; I-V: nymphs; F: females; M: males; T: Triatoma; P: Psammolestes 


\section{DISCUSSION}

The study area has undergone a strong environmental impact due to man-made practices like replacement of natural vegetation by citrus crops, Pinus sp. and Eucaliptus sp. forestation and timber extraction.

Although the 1998 flood destroyed primitive mudbricked dwellings and new wooden houses were built instead, colonies of $T$. infestans were present indoors. The finding of eggs, first instar nymphs and adults in these new houses indicated a recent infestation. The insects could have arrived from the old houses with clothes and furnitures or from neighboring ecotopes.

A high proportion of wild biotopes was infested and harbored infected vectors. This fact was not observed in peridomestic areas, which is in concordance with those results verified in other localities (Bar et al. 1996b). The epidemiological situation in peridomestic areas is not similar to other Argentinian and Brazilian regions where the levels of peridomicilies infestation are very high (Diotaiuti et al. 1994, Gajate et al. 1996).

At a settlement in Colonia Tabay, located near those wild foci, we observed a high domiciliary colonization of infected T. infestans. Besides, T. sordida was frequently found in the wild environment and showed a high natural infection index by $T$. cruzi. Under those circumstances, interaction among wild and domestic cycles may be possible and mediated by an interchange of parasites between mammals and vectors in their respective habitats. In Concepción the infestation index was similar to the one in Empedrado (Bar et al. 1997) and lower than those of other areas of the province of Corrientes (Bar et al. 1992, 1996b).

In spite of the insecticidal action carried out in the past, neither the rural health agents nor the Chagas Provincial Service followed any systematic actions. It could be concluded that these campaigns did not have enough success considering the infection and infestation results obtained in this study. A systematic residual insecticide spraying program should be applied in order to control the recovery of the vector population.

Peridomestic habitat lacked adequate structural conditions to facilitate triatomine colonization. Nevertheless the question about the ability of $T$. sordida to replace $T$. infestans inside houses still remains.

The highest densities of $T$. sordida, the most important wild vector in the studied area, were registered in spring and summer, when mainly older nymphs and adults were collected. The small number of collected females could result from early dispersion after molting probably to colonize other biotopes.

This is the first citation of $T$. sordida and $P$. coreodes in the Department of Concepcion and involves a widening of their present geographic distribution.

The seropositivity rate among the age group of higher transmission risk (0-10 years old) was similar to that reported for San Miguel (Bar et al. 1996b). However, the seroreactivity obtained in the remaining age groups revealed that humans in Concepcion show the highest rates in relation with populations from other localities (Bar et al. 1992, 1996b, 1997). The serological increasing trend was similar to those from highly endemic areas located in the western dry area of the Chaco region (Wisnivesky-Colli et al. 1989).

The infection profile of the inhabitants suggests the existence of a strong past and a moderate present trans- mission of $T$. cruzi. This control probably reflects the anti vectorial activities of the Southern Cone Initiative to eliminate T. infestans (Schofield \& Dias 1999), and call special attention to the necessity to continuous this program, under the risk to revert the actual situation to the original one, with high indexes of transmission.

\section{REFERENCES}

Bar ME, Damborsky MP, Oscherov EB, Alvarez BM, Mizdraji G, Avalos G 1997. Infestación domiciliaria por triatominos y seroprevalencia humana en el Departamento Empedrado, Corrientes, Argentina. Cad Saúde Púb 13: 305-312.

Bar ME, Oscherov EB, Avalos G, Damborsky MP, Alvarez BM 1996a. Infección natural de Triatoma sordida por Trypanosoma cruzi en ecótopos silvestres de la provincia de Corrientes, Argentina. 5ta. Jornada de Biología, Resúmenes, Asunción, Paraguay, p. 32.

Bar ME, Oscherov EB, Damborsky MP 1993. Presencia de Triatoma sordida Stål, 1859 en ecotopos urbanos de la ciudad de Corrientes, Argentina. Rev Saúde Púb São Paulo 27: 117122.

Bar ME, Oscherov EB, Damborsky MP, Alvarez BM, Mizdraji G, Avalos G, Porcel E 1996b. Infestación doméstica por Triatoma infestans y prevalencia de seropositivos al Trypanosoma cruzi en un área rural del Nordeste Argentino. Rev Soc Bras Med Trop 29: 549-555.

Bar ME, Oscherov EB, Damborsky MP, Varela ME, Mizdraji G, Porcel E 1992. Triatomismo del Departamento San Luis del Palmar de la Provincia de Corrientes, Argentina. Medicina (Bs Aires) 52: 193-201.

Cabrera AL, Willink A 1973. Biogeografía de América Latina, Programa Regional de Desarrollo Científico y Tecnológico, Secretaría General de la OEA, Washington DC, 120 pp.

Carcavallo RU, Galíndez Giron I, Jurberg J, Galvão C, Lent H 1997. Pictorial keys for tribes, genera and species of the subfamily Triatominae. In RU Carcavallo, I Galíndez Giron, J Jurberg, H Lent (eds), Atlas of Chagas' Disease Vectors in the Americas, Fiocruz, Rio de Janeiro, p. 107-244.

Diotaiuti L, Loiola CF, Falcão PL, Dias JCP 1993. The ecology of Triatoma sordida in natural environments in two different regions of the State of Minas Gerais, Brazil. Rev Inst Med Trop São Paulo 35: 237-245.

Diotaiuti L, Paula OR, Falcão PL, Dias JCP 1994. Evaluation of Chagas disease vector control programs in Minas Gerais, Brazil, wiht special reference to Triatoma sordida. Bol Of Sanit Panam 28: 211-219.

Gajate PP, Bottazzi MV, Pietrokovsky SM, Wisnivesky-Colli C 1996. Potential colonization of the peridomicile by Triatoma guasayana (Hemiptera: Reduviidae) in Santiago del Estero, Argentina. J Med Entomol 33: 635-639.

Lent H, Wygodzinsky P 1979. Revision of the Triatominae (Hemiptera, Reduviidae) and their significance as vectors of Chagas' disease. Bull Am Mus Nat History 163: 123-520.

Mozer DR, Kirchhoff LV, Donelson JE 1989. Detection of Trypanosoma cruzi by DNA amplification using the polymerase chain reaction. J Clin Microbiol 27: 1477-1482.

Russomando G, Rojas De Arias A, Almiron M, Figueredo A, Ferreira M, Morita K 1996. Trypanosoma cruzi: polymerase chain reaction-based detection in dried feces of Triatoma infestans. Exp Parasitol 83: 62-66.

Schofield CJ, Dias JCP 1999. The Southern Cone Initiative against Chagas disease. Adv Parasitol 42: 1-27.

Wisnivesky-Colli C, Gurtler RE, Solarz ND, Schweigmann NJ, Pietrokowsky SM, Alberti A, Flo J 1993. Dispersive flight and house invasion by Triatoma guasayana and Triatoma sordida in Argentina. Mem Inst Oswaldo Cruz 88: 27-32.

Wisnivesky-Colli C, Paulone I, Perez A., Chuit R, Gualtieri J, Solarz ND, Smith A, Segura EL 1987. A new tool for continuous detection of the presence of triatomine bugs, vectors of Chagas disease, in rural households. Medicina (Bs Aires) 47: $45-50$ 
Wisnivesky-Colli C, Ruiz AM, Gurtler RE, Solarz ND, Lazzari J, Ledesma O, Bujas MA, Rissio AM, Marteleur A, Segura EL 1989. Dynamics of transmission of Trypanosoma cruzi in a rural area of Argentina. IV. Serologic, parasitologic and electrocardiographic study of the human population. Medicina (Bs Aires) 49: 341-350. 